\title{
An in vitro antiviral activity of iodine complexes against SARS-CoV-2
}

\author{
Imran Altaf ${ }^{1} \cdot$ Muhammad Faisal Nadeem $^{2} \cdot$ Nadir Hussain $^{1} \cdot$ Muhammad Nawaz $^{1} \cdot$ Sohail Raza $^{1}$. \\ Muhammad Abu bakr Shabbir ${ }^{1}$. Muhammad Adnan Ashraf ${ }^{1}$. Muhammad Asad Ali ${ }^{1}$. Sohail Hassan ${ }^{1}$. \\ Muhammad Waqar Aziz ${ }^{1}$. Nazish Matti ${ }^{3}$. Muhammad Ashraf ${ }^{3}$. Ihsan Ulla ${ }^{4}$. Sehar Fazal ${ }^{1}$. Saira Rafique ${ }^{1}$. \\ Adnan Mehmood ${ }^{1}$. Nageen Sardar ${ }^{1} \cdot$ Muhammad Tahir Khan $^{1} \cdot$ Hafiz Muhammad Moavia Atique ${ }^{1} \cdot$ Sohaib Ashraf $^{5}$. \\ Zarfishan Tahir $^{6} \cdot$ Nadia Mukhtar $^{6} \cdot$ Tahir Yaqub $^{1}$ (1)
}

Received: 26 March 2021 / Revised: 24 May 2021 / Accepted: 8 June 2021 / Published online: 16 June 2021

(c) The Author(s), under exclusive licence to Springer-Verlag GmbH Germany, part of Springer Nature 2021

\begin{abstract}
Since the emergence of COVID-19 pandemic in China in late 2019, scientists are striving hard to explore non-toxic, viable anti-SARS-CoV-2 compounds or medicines. We determined In vitro anti-SARS-CoV-2 activity of oral formulations (syrup and capsule)of an Iodine-complex (Renessans). First, cell cytotoxicity of Renessans on the Vero cells was determined using MTT assay. Afterwards, the antiviral activity of Renessans was determined using viral inhibition assays and TCID $_{50}$. For this, nontoxic concentrations of the Renessans were used. The results showed that Renessans is nontoxic to the cells up to $50 \mu \mathrm{g} / \mathrm{mL}$. At $1.5 \mu \mathrm{g} / \mathrm{mL}$ concentration, SARS-CoV-2 production was significantly reduced to $10^{1.43} \mathrm{TCID}_{50}$ and $10^{1.58}$ $\mathrm{TCID}_{50}$ for the syrup and capsule, respectively, as compare to virus infected control cells $10^{6.08} \mathrm{TCID}_{50}$ and we found the dose dependent inhibition of virus replication in the presence of Renessans. Renessans inhibited SARS-CoV-2 with an EC50 value of $0.425 \mu \mathrm{g} / \mathrm{mL}$ and $0.505 \mu \mathrm{g} / \mathrm{mL}$ for syrup and capsule, respectively. Furthermore, there was no virus detected at concentration of $50 \mu \mathrm{g} / \mathrm{mL}$ of Renessans. This study indicates that Renessans, containing iodine, have potential activity against SARS-CoV-2 which needs to be further investigated in human clinical trials.
\end{abstract}

Keywords COVID-19 · SARS-CoV-2 · Virus · Iodine complex $\cdot$ Renessans

Communicated by Erko Stackebrandt.

Tahir Yaqub

tahiryaqub@uvas.edu.pk

1 Institute of Microbiology, University of Veterinary and Animal Sciences, Lahore, Pakistan

2 Institute of Pharmaceutical Sciences, University of Veterinary and Animal Sciences, Lahore, Pakistan

3 Department of Pharmacology, University of Veterinary and Animal Sciences, Lahore, Pakistan

4 Institute of Biochemistry and Biotechnology, University of Veterinary and Animal Sciences, Lahore, Pakistan

5 Department of Cardiology, Sheikh Zaid Hospital Lahore, Lahore, Pakistan

6 Institute of Public Health, Lahore, Pakistan

\section{Introduction}

The SARS-CoV-2 is a novel coronavirus that was first reported in December 2019 in Wuhan, China. The virus was named as 2019-nCoV (2019 novel coronavirus) by World Health Organization (WHO) (Chen 2020). The International Committee on Taxonomy of Viruses renamed it as Severe Acute Respiratory Syndrome Coronavirus-2 (SARS-CoV-2) on 11 February 2020 (Alexander 2020). The infection was termed as Coronavirus Disease (COVID-19) and its worldwide spread forced the WHO to declare it a global pandemic, i.e., public health emergency of international concern (PHEIC) (Zarocostas 2020).

Since SARS-CoV-2 infection is a recent emergence in the field of medicine, there is no predefined standard therapeutic course to follow. Most of the treatment regimens revolve around the previous pathophysiological viruses/diseases similar to COVID-19 (Guo 2020; Jin 2020). Due to a rapid surge in data regarding COVID-19, new clinical findings are paving a way forward for more informed decisions in 
the selection of appropriate therapeutic regimens. Such regimens are focused upon symptomatic relief (e.g. respiratory), amelioration of underlying pathological phenomena (antiinflammatory) and antiviral effects. With a hope to devise an appropriate but definite cure, re-purposing of already available therapeutic options, evidence-based medicine, and traditional therapies are being tested ( $\mathrm{Ng}$ and Bezak 2020) with anecdotal outcomes. For instance, viral fusion inhibitor (arbidol) and protease inhibitors (lopinavir and ritonavir) failed to reduce the negative conversion time of novel coronavirus nucleic acid in pharyngeal swab or improving the symptoms (Deng, 2020). Danoprevir (an anti-HCV drug), on the other hand, has completed the participants recruitment for treating the viral pneumonia in combination with ritonavir (Iyer 2020). Another drug boceprevir has shown to inhibit viral replication during recent experiments (Ma et al. 2020). These are a few examples of projects going-on to discover possible treatment of coronavirus infection, while there are many experiments in clinical trials (Lythgoe and Middleton 2020).

Another area is to explore potential micronutrients and vitamins in the treatment of SARS-CoV-2. An extraneous administration of micronutrients is supposed to overcome the nutritional deficiencies and strengthen the immune system of the patient (Belsky et al. 2018; Elmadfa and Meyer 2019). Currently, in the subject matter, many clinical trials are going on to evaluate the efficacy of vitamin D and C in COVID-19 patients (Carr 2020; Grant 2020). A recent study revealed antiviral properties of lithium in preclinical studies for COVID-19 (Murru 2020). Though use of micronutrient is already exemplified by the addition of zinc to chloroquine therapy (Shittu and Afolami 2020), the direct antiviral potential of micronutrients is still an area wide open for research. Among the micronutrients, Iodine has known antimicrobial properties, therefore, used in topical applications (Norman et al. 2016). Besides a role for inactivation of enveloped and non-enveloped viruses (Wood and Payne 1998), its use in physical inactivation of SARS-CoV-1, MERS has already been demonstrated (Kariwa et al. 2006; Eggers et al. 2015). However, the use of iodine as a systemic intervention is yet debatable for its toxicity (Leung and Braverman 2014).

The most common method to increase body iodine concentration is iodine intake through the use of iodine supplements (Niwattisaiwong et al. 2017). Kelp is a dried seaweed rich in vitamins, and minerals especially iodine where iodine is complexed with other components. It has traditionally been used as a galactagogue and a weight loss cure (Vaughn 2012). An iodine complex formulation has been patented (patent no: 141316, IPO, Pakistan) and registered by MTI, Pakistan (DRAP registration \# 505620098). Its clinical trials have successfully been conducted where it was found to be highly effective in the treatment of oligomenorrhea and polycystic fibrosis (Iftikhar 2013; Naqvi 2014). Moreover, its antiviral efficacy has also been reported for clinical trial against Hepatitis C Virus (HCV). Indeed, in combination with traditional therapy, iodine complex has been associated with excellent antiviral response in chronic $\mathrm{HCV}$ patients (Nabi et al. 2020). Antiviral activity of said complex (Renessans) has also been tested for avian influenza virus where it showed inhibition of cytopathic effects (Matti et al. 2020).

With this background, considering the previous potential of study drug, we investigated antiviral potential of Iodine complex against SARS-CoV-2 to suggest a readily available compound which has a proven antiviral efficacy.
Fig. 1 Cell cytotoxicity for Renessans syrup and capsule. a Non-toxic concentrations of the Renessans syrup was measured using MTT assay. b Non-toxic concentrations of the Renessans capsule was measured using MTT assay
A

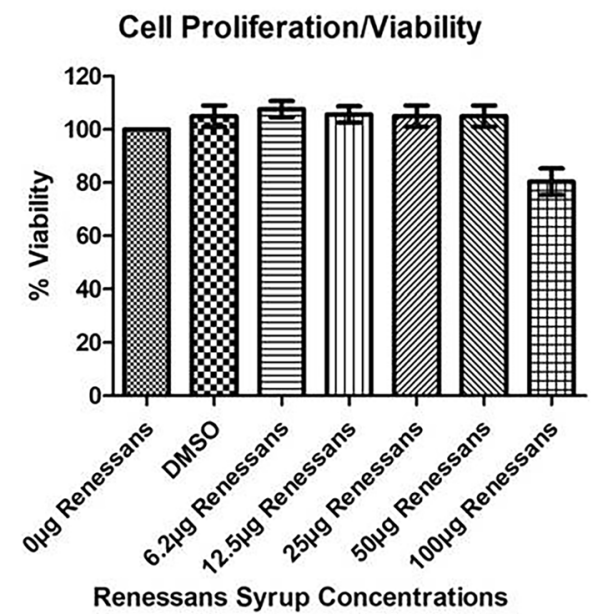

B

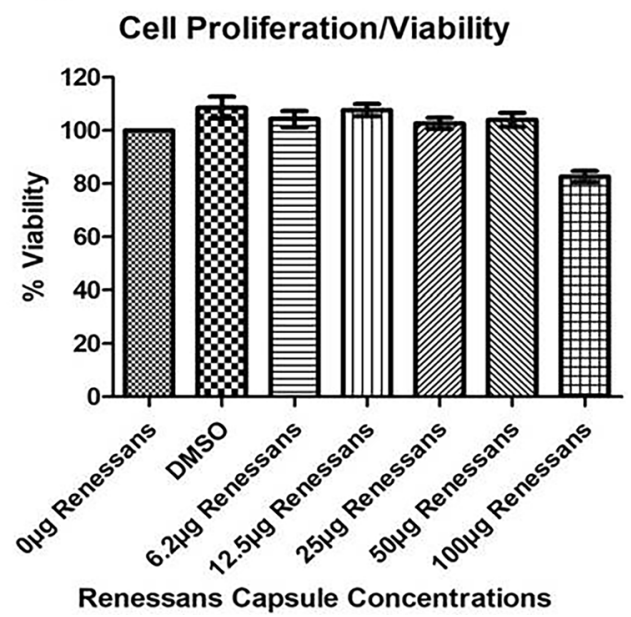


Table 1 Effect of RENESSANS syrup and capsule on the production of SARS-CoV-2 in VERO Cells culture system

\begin{tabular}{|c|c|c|}
\hline Formulation & $\begin{array}{l}\text { Concentration of drug } \\
(\mu \mathrm{g} / \mathrm{mL})\end{array}$ & $\mathrm{TCID}_{50}$ \\
\hline \multirow[t]{11}{*}{ Renessans syrup } & 50 & 0 \\
\hline & 25 & 0 \\
\hline & 12.5 & 0 \\
\hline & 6.2 & 0 \\
\hline & 3.1 & 0 \\
\hline & 1.5 & $1 \times 10^{1.43}$ \\
\hline & 0.75 & $1 \times 10^{1.47}$ \\
\hline & 0.35 & $1 \times 10^{3.83}$ \\
\hline & 0.17 & $1 \times 10^{4.81}$ \\
\hline & 0.08 & $1 \times 10^{5.79}$ \\
\hline & 0.04 & $1 \times 10^{5.82}$ \\
\hline \multirow[t]{11}{*}{ Renessans capsule } & 50 & 0 \\
\hline & 25 & 0 \\
\hline & 12.5 & 0 \\
\hline & 6.2 & 0 \\
\hline & 3.1 & 0 \\
\hline & 1.5 & $1 \times 10^{1.58}$ \\
\hline & 0.75 & $1 \times 10^{1.82}$ \\
\hline & 0.35 & $1 \times 10^{5.08}$ \\
\hline & 0.17 & $1 \times 10^{5.67}$ \\
\hline & 0.08 & $1 \times 10^{5.72}$ \\
\hline & 0.04 & $1 \times 10^{5.77}$ \\
\hline SARS CoV-2 control (PC) & None & $1 \times 10^{6.08}$ \\
\hline Cell control (NC) & None & 0 \\
\hline
\end{tabular}

All the values that shows virus titers are bold

\section{Materials and methods}

\section{Drugs}

RENESSANS capsule (containing $200 \mathrm{mg}$ iodine) and syrup (containing $10 \mathrm{mg} / \mathrm{ml}$ iodine) were prepared and provided by MTI Medical Pvt. Ltd. for this study. Each capsule contains: polyiodides as iodine/iodide equivalent to $200 \mathrm{mg}$ iodine/ iodide; Excipients: polysaccharides $250 \mathrm{mg}$ and ascorbic acid $5 \mathrm{mg}$. For suspension: each $10 \mathrm{ml}$ contains: polyiodides as iodine/iodide equivalent to $50 \mathrm{mg}$ iodine/iodide; Excipients: glycerine $2 \mathrm{ml}$ and ascorbic acid $2 \mathrm{mg}$, sorbitol $1 \mathrm{ml}$ and water.

\section{Revival and establishment of VERO cell line monolayer}

Vero cells were obtained from Institute of Microbiology, University of Veterinary Animal Sciences (UVAS) Lahore, Pakistan. Dulbecco's Modified Eagle Medium (DMEM) cell culture along with $10 \%$ fetal bovine serum was used to revive vero cells (Ammerman et al. 2008). Monolayer of these cells was established and maintained in $25 \mathrm{~cm}^{2}$ roux flasks. The flasks were observed for $48 \mathrm{~h}$ for any kind of bacterial or fungal contamination. The flasks with $80 \%$ monolayer were selected for viral replication and antiviral activity of drugs.

\section{Virus cultivation and isolation}

SARS-CoV-2 (MW031799) was isolated previously from a clinical sample in BSL- 3 laboratory located in the Institute of Microbiology, UVAS, Lahore, Pakistan. The isolate was identified using commercially available real-time PCR kit (Sansure BioTech, Changsha, China) as per manufacturer's instruction. Cell culture flasks with $80 \%$ monolayer were used and infected with SARS-CoV-2 isolate. DMEM cell culture media containing $1 \%$ fetal bovine serum was used for infection. After $72 \mathrm{~h}$ of incubation, cytopathic effects were observed and virus replication was confirmed by real $50 \%$ tissue culture infective dose $\left(\mathrm{TCID}_{50}\right)$ (Araujo 2020).

\section{Preparation of drug concentrations:}

Different concentrations of drugs from 0.04 to $100 \mu \mathrm{g} / \mathrm{mL}$ were prepared and reconstituted in same media used for Vero cell. First, the cytotoxicity profile of drugs was checked and non-cytotoxic concentrations were selected for the evaluation of antiviral profile in-vitro cell culture.

\section{Cytotoxicity assay}

Different drug concentrations that were selected for antiviral activity were mixed into cell culture media and added into confluent vero cells. MTT assay kit (Abcam, Cambridge, UK) following the manufacturer's instructions was used to perform the cytotoxicity assay.

\section{In-vitro antiviral activity}

The non-cytotoxic concentrations of the drug were selected for the evaluation of antiviral profile in vitro cell culture against SARS-CoV-2. Vero cells grown in 6-well tissue culture plates in the presence of DMEM along with 10\% FBS. Confluent Vero cells were infected with SARS-CoV-2 at concentration of $10^{6.08} \mathrm{TCID}_{50}$ for $2 \mathrm{~h}$ at $37^{\circ} \mathrm{C}$. After internalization of the virus, the inoculum was removed and cells were washed for three times. After washing, fresh media along with different concentrations of Renessans were added and incubated for $72 \mathrm{~h}$. Mock-infected and infected non-treated controls were also run in parallel. After $72 \mathrm{~h}$, the cell lysate were collected 
A

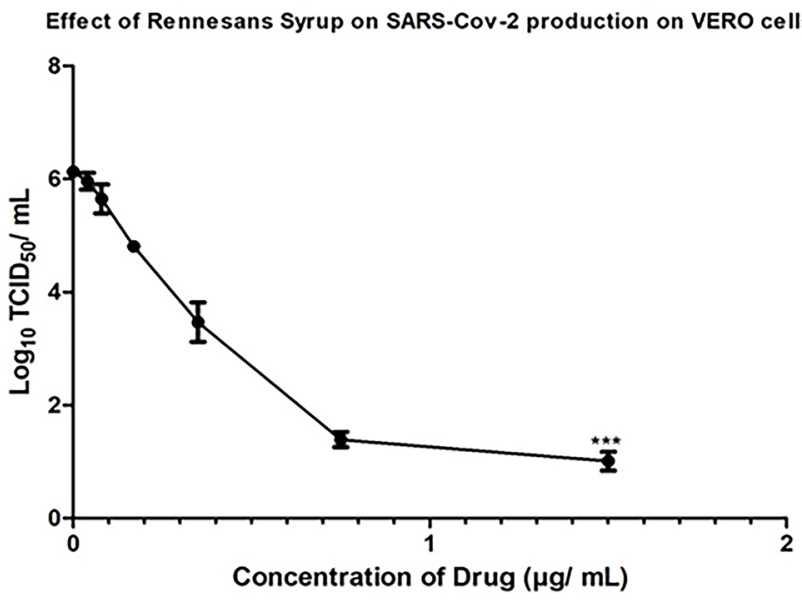

C

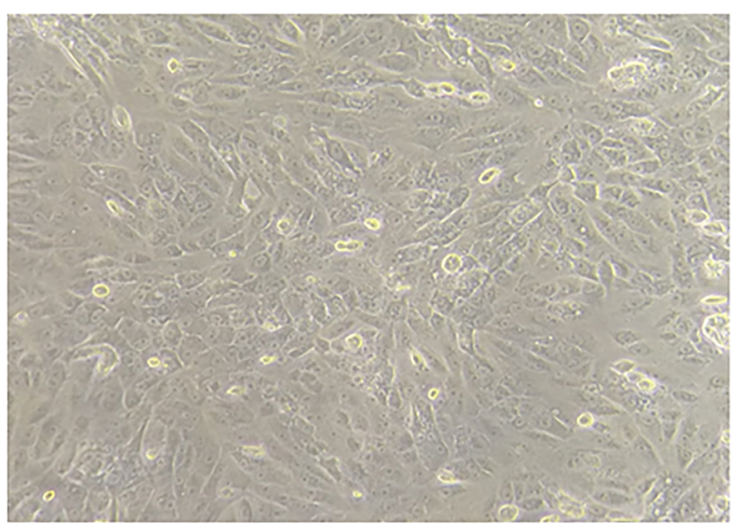

B

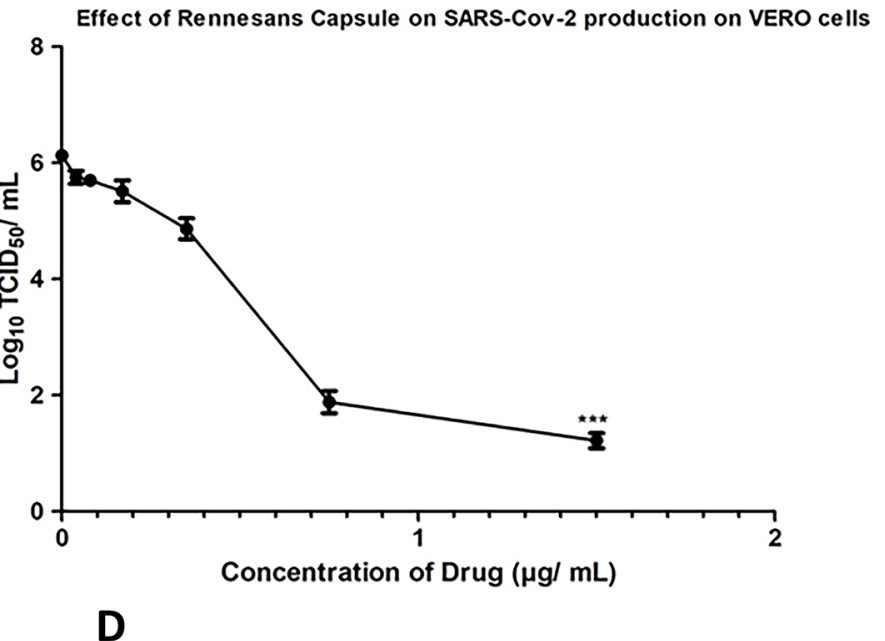

Fig. 2 Antiviral effect of Renessans against SARS-CoV-2. a Effect of Renessans syrup on SARS-CoV-2 production on vero cells. b Effect of Renessans Capsule on SARS-CoV-2 production on vero cells. c

after three cycles of freeze/thaw. Virus titers were measured as $50 \%$ tissue culture infective dose $\left(\mathrm{TCID}_{50}\right)$.

\section{Statistical analysis}

All the experiments were performed three times individually, and the data were presented as means \pm standard deviation (SD). The results were analyzed by Graph pad prism software (version 6.0). Student's $t$-test was applied to the results to compare the means of the $\mathrm{TCID}_{50}$ value of the test group with the control. Statistical significance represented by asterisks is marked correspondingly in the figures $(* p<0.05, * * p<0.01, * * * p<0.001)$.

\section{SARS-CoV-2 at $200 \mathrm{X}$}

\section{Results}

The cytotoxicity assay confirmed that up to $50 \mu \mathrm{g}$ concentration of Renessans syrup and Renessans capsule was nontoxic to the cells (Fig. 1A, B). The VERO cells were exposed to SARS-CoV-2 with and without different non-toxic concentration of Renessans capsule and syrup. Effect of Renessans capsule and syrup on the growth of virus on vero cells monolayer is given in Table 1. At the concentration of $0.04 \mu \mathrm{g} / \mathrm{mL}$, the virus titers were reduced to $10^{5.82} \mathrm{TCID}_{50}$ and $10^{5.77} \mathrm{TCID}_{50}$ for Renessans syrup and capsule, respectively, as compare to infected non treated control cells having $10^{6.08} \mathrm{TCID}_{50}$. As the concentration of the drug increases the virus titers were reduced upto $10^{1.43} \mathrm{TCID}_{50}$ and $10^{1.58}$ $\mathrm{TCID}_{50}$ for the Renessans syrup and capsule, respectively, at concentration of $1.5 \mu \mathrm{g} / \mathrm{mL}$ as compare to infected non-treated control cells with $10^{6.08} \operatorname{TCID}_{50}$ (Fig. 2A, B). The results showed dose dependent antiviral behavior of 
Fig. 3 Half maximal effective concentration $\left(\mathrm{EC}_{50}\right)$ of RENESSANS. a $\mathrm{EC}_{50}$ of RENESSANS syrup was calculated using different concentrations of RENESSANS syrup b $\mathrm{EC}_{50}$ of RENESSANS capsule was calculated using different concentrations of RENESSANS capsule. All the experiments were conducted in triplicate and mean values are used to calculate $\mathrm{EC}_{50}$

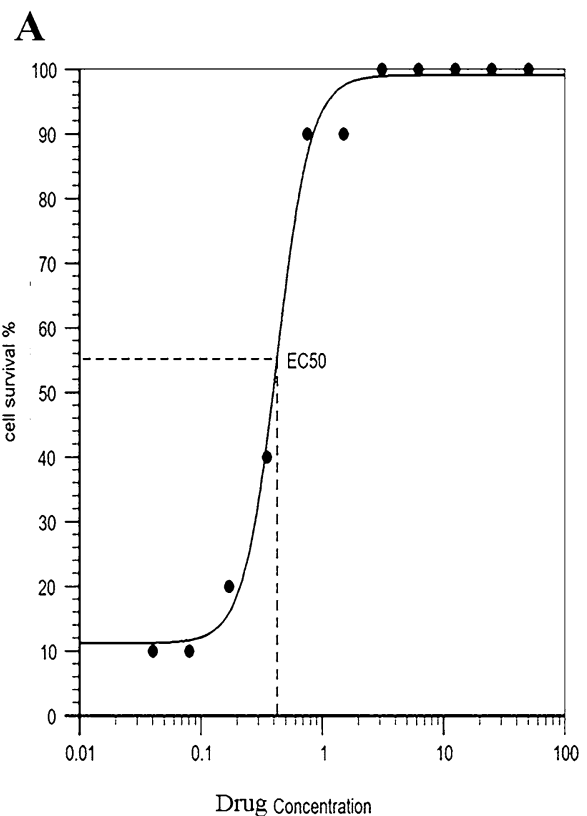

\section{B}

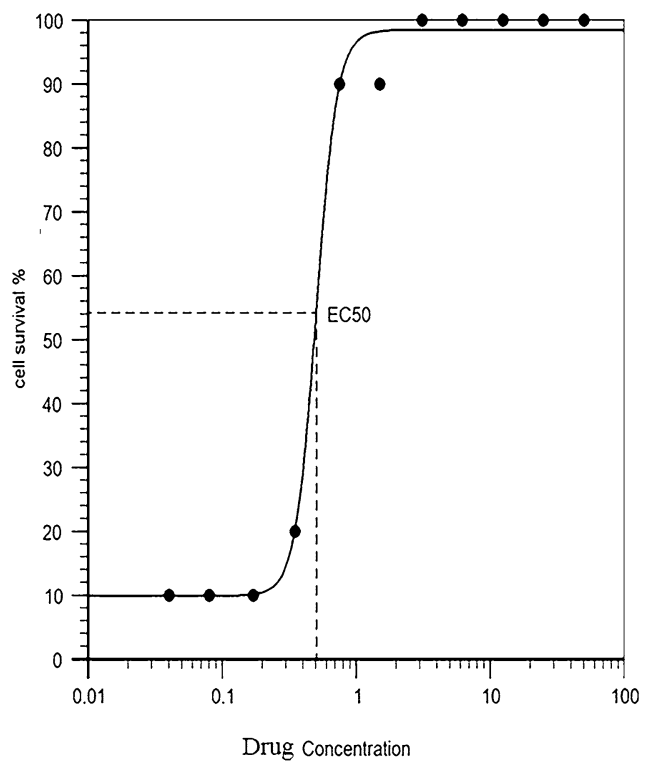

Renessans syrup and capsule against SARS-CoV-2 (Fig. 2C, D). Interestingly, at a concentration of $3.1-50 \mu \mathrm{g} / \mathrm{mL}$ of Renessans syrup and capsule, there was complete inhibition in virus production and no virus were detected after $72 \mathrm{~h}$. The $\mathrm{EC}_{50}$ of Renessans syrup was $0.425 \mu \mathrm{g} / \mathrm{mL}$ and Renessans capsule was $0.505 \mu \mathrm{g} / \mathrm{mL}$ (Fig. 3A, B).

\section{Discussion}

COVID-19 pandemic is caused by SARS-CoV-2, and is considered the most significant threat to human lives in the world today. It is showing no signs of slowing down. On one hand, the world is racing to find the cure against this newly emerged virus through developing vaccines and antivirals. Various vaccines have been developed on different platforms, are being used for mass vaccinations viz. Pfizer-BioNTech \& Moderna (mRNA), Oxford-AstraZeneca (Ch AdOx 1), Sinovac $\&$ Bharat Biotech (inactivated) (Carl Zimmer 2021). Indeed, antiviral drug is considered to be the most probable and urgent cure for the COVID-19. However, new development of antiviral against SARS-CoV-2 may require years that initiates the potential repurposing the existing approved antivirals/antimicrobials against SARS-CoV-2. In this context, ivermectin (Caly et al. 2020), Hydroxychloroquin (Cohen 2020), Arbidol (Eggers et al. 2015) and many others have been tested against SARS-CoV-2. WHO drops hydroxychloroquine (HCQ) from clinical trials after available data indicated that the drug has no effect against COVID-19 (Kariwa et al. 2006). Ivermectin exposure to cells exhibited significant reduction in virus titers as compare to control cells. The trials for the clinical use of Ivermectin against COVID-19 are in progress.
In this study, we evaluated the anti SARS-CoV-2 activity of iodine complex (Renessans) that has already been approved for human use. Iodine has a history of use in tropical applications and exhibited antiviral activity against SARS-CoV, MERS, avian influenza virus and HCV. We have used non-toxic concentrations of Renessans. At these concentrations, Renessans exhibited strong antiviral activity against SARS-CoV-2 with no/few CPE were observed in drug treated cells as compare to control cells. In vitro results exhibited that Renessans in the form of syrup and tablet lead to complete inhibition of virus production at $50 \mu \mathrm{g} / \mathrm{mL}$. This may predict the use of Renessans in the form of syrup as compare to capsule form. In line with the cell morphological analysis, $\mathrm{TCID}_{50}$ data revealed that the virus replication was greatly inhibited in the drug treated cells as compare to control cells. In a recent study, the antiviral activity of CupriDyne, an iodine complex disinfectant solution was evaluated against SARS-CoV-2. This iodine solution was able to inactivate the virus in time dependent manner, reducing the virus titers by $99 \%$ and reducing the virus titers below detection limit after $60 \mathrm{~min}$ (Mantlo et al. 2020). Similarly, iodine complex had exhibited a virucidal activity against MERS virus, the virus inactivation of $\geq 99.99 \%$ within 15 s of application. Moreover, iodine product had reduced the SARS$\mathrm{CoV}$ infectivity to undetectable levels in $2 \mathrm{~min}$ of exposure in Vero infected Cells (Mullard 2020). Collectively, the previous data confirms our finding of iodine complexes, which have showed strong antiviral activity against SARS-CoV-2 and members of this family. Moreover, iodine has also exhibited its antiviral potential against other viruses like in human and avian influenza virus, iodine was able to inhibit the influenza A viruses infection by up to $97.5 \%$ in MDCK-infected cells (Singh et al. 2020), adenoviral conjunctivitis (Sriwilaijaroen 
2009), and Modified vaccinia virus Ankara (Wang 2020). Based on the previous literature addressing the mechanism involved in the activity of iodine against SARS, it is more likely that iodine makes the structural changes on the viral coat through attack on histidine and tyrosine residues (Mantlo et al. 2020). Thus, it is likely that inhibition of SARS-CoV-2 infection at the entry level by blocking the viral attachment to the cell. Indeed, this seems to be a general mechanism underlying the inhibitory effect of iodine on other viruses, including human and avian influenza viruses.

\section{Conclusions}

This study indicates that RENESSANS (iodine containing oral formulation), have potential activity against SARSCoV-2 which needs to be further investigated in human clinical trials.

Author contributions Conceptualization, TY, MN, ZT, IA; methodology, IA, MFN, NH, IU, SF, SR, MA, NS, TK, MM, SA; formal analysis, NM, MN, IA, MAA; writing-original draft preparation, SR, MAbS, MAA; writing - review and editing, TY, IA, MN, SR. All authors have read and agreed to the published version of the manuscript.

\section{Declarations}

Conflict of interest The authors declare no conflict of interest.

Ethical approval This article does not contain any studies with human participants or animals performed by any of the authors.

\section{References}

Alexander E, Gorbalenya AAG, Lauber C, Sidorov IA, Leontovich AM, Penzar D, Samborskiy DV, Baker SC, Baric RS, de Groot RJ, Drosten C, Haagmans BL, Neuman BW, Perlman S, Poon LLM, Sola I, Ziebuhr J (2020) The species Severe acute respiratory syndrome-related coronavirus: classifying 2019-nCoV and naming it SARS-CoV-2. Nat Microbiol 5:536-544. https://doi. org/10.1038/s41564-020-0695-z

Ammerman NC, Beier-Sexton M, Azad AF (2008) Growth and maintenance of vero cell lines. Curr Protoc Microbiol. https://doi.org/ 10.1002/9780471729259.mca04es11

Araujo DB et al (2020) SARS-CoV-2 isolation from the first reported patients in Brazil and establishment of a coordinated task network. Mem Inst Oswaldo Cruz 115:e200342. https://doi.org/10.1590/ 0074-02760200342

Belsky JB, Wira CR, Jacob V, Sather JE, Lee PJ (2018) A review of micronutrients in sepsis: the role of thiamine, l-carnitine, vitamin C, selenium and vitamin D. Nutr Res Rev 31:281-290

Caly L, Druce JD, Catton MG, Jans DA, Wagstaff KM (2020) The FDA-approved drug ivermectin inhibits the replication of SARSCoV-2 in vitro. Antivir Res 178:104787. https://doi.org/10.1016/j. antiviral.2020.104787
Carl Zimmer J-LW (2021) Coronavirus vaccine tracker. The new york times. The New York Times Company, New York

Carr AC (2020) A new clinical trial to test high-dose vitamin C in patients with COVID-19. Crit Care 24:1-2

Chen $\mathrm{N}$ et al (2020) Epidemiological and clinical characteristics of 99 cases of 2019 novel coronavirus pneumonia in Wuhan, China: a descriptive study. Lancet 395:507-513

Cohen MS (2020) Hydroxychloroquine for the prevention of covid19-searching for evidence. N Eng J Med. https://doi.org/10. 1056/nejme2020388

Deng L et al (2020) Arbidol combined with LPV/r versus LPV/r alone against corona virus disease 2019: a retrospective cohort study. J Infect 81(1):e1-5

Eggers M, Eickmann M, Zorn J (2015) Rapid and effective virucidal activity of povidone-iodine products against middle east respiratory syndrome coronavirus (MERS-CoV) and modified vaccinia virus Ankara (MVA). Infect Dis Ther 4:491-501. https://doi.org/ 10.1007/s40121-015-0091-9

Elmadfa I, Meyer AL (2019) The role of the status of selected micronutrients in shaping the immune function. Endocr Metab Immune Disord Drug Targ Former Curr Drug Targ Immune Endocr Metab Disord 19:1100-1115

Grant WB et al (2020) Evidence that vitamin D supplementation could reduce risk of influenza and COVID-19 infections and deaths. Nutrients 12:988-988

Guo Y-R et al (2020) The origin, transmission and clinical therapies on coronavirus disease 2019 (COVID-19) outbreak-an update on the status. Mil Med Res 7:1-10

Iftikhar R (2013) The miracle of iodine complex in treatment of cases of polycystic ovarian disease induce by subclinical hypothyroidism. Isra Med J 5:185-188

Iyer M et al (2020) COVID-19: an update on diagnostic and therapeutic approaches. BMB Rep 53:191-191

Jin $Y$ et al (2020) Virology, epidemiology, pathogenesis, and control of COVID-19. Viruses 12:372-372

Kariwa H, Fujii N, Takashima I (2006) Inactivation of SARS coronavirus by means of povidone-iodine, physical conditions and chemical reagents. Dermatology 212(Suppl 1):119-123. https:// doi.org/10.1159/000089211

Leung A, Braverman L (2014) Consequences of excess iodine. Nat Rev ENdocrinol 10:136-142. https://doi.org/10.1038/nrendo. 2013.251.Consequences

Lythgoe MP, Middleton P (2020) Ongoing clinical trials for the management of the COVID-19 pandemic. Trends Pharmacol Sci 41(6):363-382

Ma C et al. (2020) Boceprevir, GC-376, and calpain inhibitors II, XII inhibit SARS-CoV-2 viral replication by targeting the viral main protease. Cell Res 30:678-692 https://doi.org/10.1038/ s41422-020-0356-z

Mantlo E, Evans A, Patterson-Fortin L, Boutros J, Smith R, Paessler S (2020) Efficacy of a novel iodine complex solution, CupriDyne, in inactivating SARS-CoV-2. bioRxiv. https://doi.org/10.1101/ 2020.05.08.082701

Matti N, Ashraf M, Rasheed MA, Altaf I, Carvalho I, Nadeem MF (2020) Evaluation of cytotoxic, antiviral effect and mutagenic potential of a micronutrient combination in vitro cell culture. BioRxiv. https://doi.org/10.1101/2020.06.18.160333

Mullard A (2020) COVID-19 vaccine development pipeline gears up. Lancet 395:1751-1752. https://doi.org/10.1016/S0140-6736(20) 31252-6

Murru A et al (2020) Lithium's antiviral effects: a potential drug for CoViD-19 disease? Int J Bipolar Disord 8:1-9

Nabi G, Nasir M, Toor I, Zia F, Hassan I, Nadeem MFF (2020) An Open Labelled, Active Controlled, Three-Arm, Parallel-Group study of the safety and efficacy of the oral formulation of Oral Iodine Complex (RENESSANS) administered alone and in 
combination with standard interferon therapy in patients suffering from Chronic HCV Hepatitis. medRxiv - Gastroenterology https://doi.org/10.1101/2020.06.27.20141473

Naqvi AKAMS (2014) To determine the role of iodine polymers (idomarine) in the treatment of oligomenorrhea and polycystic ovarian disease in students for Sir Syed Medical College for Girls Karachi. J Fatima Jinnah Med Univ 8:64-68

$\mathrm{Ng} \mathrm{KH}$, Bezak E (2020) Prejudice in science-the coronavirus story. physica medica. Eur J Med Phys 75:83-84 https://doi.org/10. 1016/j.ejmp.2020.06.011

Niwattisaiwong S, Burman KD, Li-Ng M (2017) Iodine deficiency: clinical implications. Cleve Clin J Med 84:236-244

Norman G, Dumville JC, Mohapatra DP, Owens GL, Crosbie EJ (2016) Antibiotics and antiseptics for surgical wounds healing by secondary intention. Cochrane Database Syst Rev 3:CD011712 https:// doi.org/10.1002/14651858.CD011712.pub2

Shittu MO, Afolami OI (2020) Improving the efficacy of chloroquine and hydroxychloroquine against SARS-CoV-2 may require zinc additives-a better synergy for future COVID-19 clinical trials. Infez Med 28:192-197

Singh AK, Singh A, Shaikh A, Singh R, Misra A (2020) Chloroquine and hydroxychloroquine in the treatment of COVID-19 with or without diabetes: a systematic search and a narrative review with a special reference to India and other developing countries. Diabetes Metab Syndr 14:241-246. https://doi.org/10.1016/j.dsx. 2020.03.011

Sriwilaijaroen N et al (2009) Mechanisms of the action of povidoneiodine against human and avian influenza $A$ viruses: its effects on hemagglutination and sialidase activities. Virol J 6:124. https:// doi.org/10.1186/1743-422X-6-124

Vaughn CJ (2012) Drugs and lactation database: lactmed. J Electron Resour Med Libr 9:272-277

Wang X et al (2020) The anti-influenza virus drug, arbidol is an efficient inhibitor of SARS-CoV-2 in vitro. Cell Discov 6:28. https:// doi.org/10.1038/s41421-020-0169-8

Wood A, Payne D (1998) The action of three antiseptics/disinfectants against enveloped and non-enveloped viruses. J Hosp Infect $38: 283-295$

Zarocostas J (2020) What next for the coronavirus response? Lancet 395:401. https://doi.org/10.1016/S0140-6736(20)30292-0

Publisher's Note Springer Nature remains neutral with regard to jurisdictional claims in published maps and institutional affiliations. 